\title{
A longitudinal study of factors predicting students' intentions to leave upper secondary school in Norway
}

\author{
Jan Arvid Haugan $^{1}$ (D) $\cdot$ Per Frostad $^{1} \cdot$ Per-Egil Mjaavatn ${ }^{1}$
}

Received: 20 August 2018 / Revised: 10 September 2019 / Accepted: 11 September 2019 /

Published online: 24 September 2019

(C) The Author(s) 2019

\begin{abstract}
This article illuminates factors predicting students' intention to leave upper secondary school. The research is anchored in an ecological theoretical perspective that considers dropout as a multifaceted phenomenon that culminates in the decision to leave school. Based on this, we have used a longitudinal research design to investigate to what extent factors related to students' experiences predict their intention to leave school early. The sample in this study comprises 1695 students from upper secondary schools in the county of Trøndelag in Norway. We ran descriptive analyses, correlations and hierarchical regression to analyse our data. In the stepwise causal modelling, the independent variables were placed in the same order as the hypotheses were formulated. This enabled us to test each of the independent variables to explain how much variance there was in the dependent variable (intention to leave) beyond those entered in the previous steps. The results show that the students' grades from elementary school, parental and teacher support and school engagement in upper secondary school are important explanatory factors leading to dropout. Loneliness at secondary school and students' ability to cope with stressful life events seem to be the two most important predictive factors in relation to the students' thoughts about leaving.
\end{abstract}

Keywords Dropout $\cdot$ Upper secondary $\cdot$ Predicting factors $\cdot$ Loneliness

Jan Arvid Haugan

jan.haugan@ntnu.no

Per Frostad

per.frostad@ntnu.no

Per-Egil Mjaavatn

per.egil.mjaavatn@ntnu.no

1 Norwegian University of Science and Technology, Trondheim, Norway 


\section{Introduction}

Dropout from upper secondary school is a prevalent problem in both North American and European countries. However, across the OECD countries, the share of 25-34 year olds that have not completed upper secondary school has decreased from $35 \%$ in 2000 to $29 \%$ in 2005, 26\% in 2010 and 22\% in 2016 (OECD 2017). Even so, as more than one in five young adults do not complete upper secondary school, dropout is a considerable challenge in western societies. First, because of the prominent national socio-economic consequences. In Norway, a report conducted on behalf of the Ministry of Education and Research concluded that every 1\% percent dropout costs the nation between NOK 540-880 million or approximately USD 73-119 million every year (Falch et al. 2009). Second, because leaving school has negative consequences for the dropouts themselves. Compared to those who complete upper secondary school, individuals who drop out will face a gloomy economic future as they have poorer job prospects, are more likely to be welfare recipients and earn a lower income than their more educated peers on average (Falch et al. 2010; Rumberger 2011). Furthermore, research indicates that dropouts also have more criminal behaviour, and poorer mental and physical health (De Ridder et al. 2012; Rumberger and Lamb 2003). As a result, dropouts apparently have a more difficult and shorter life span compared with their more educated peers.

\subsection{Upper secondary school in Norway}

The compulsory elementary school in Norway consists of 10 years of educationseven in primary school and three in lower secondary school. Upper secondary school is not compulsory, but the publicly funded education provides adolescents up to 21 years a statutory right. Almost $98 \%$ of the students who complete elementary school in 10th grade immediately enrol in upper secondary education (Statistics Norway 2018). The students have to compete for a place in their preferred study programme based on their grade point average from elementary school. Three choices of study programme can be listed, and students are guaranteed admission to at least one of these. The total number of available study programmes in 2018 is 13, five in the general programme that lasts for 3 years and qualifies for higher education, and eight in the vocational study programme. The vocational programmes last for 4 years, comprising 2 years in school and 2 years of apprenticeship. Students in these programmes can also choose to leave the apprenticeship system and complete a general academics course after their first 2 years of schooling, and following successful completion, qualify for higher education.

The attainment of upper secondary school education is defined as successful completion within 5 years. The number that do not finish upper secondary school has fluctuated around 30\% since 1994 (Holen et al. 2017; Markussen et al. 2011). The last statistics show that among all of the students that started upper secondary school in autumn 2012, $73 \%$ reached attainment (70\% of the boys, and $80 \%$ of the girls) (Statistics Norway 2018). Students in the general studies programmes complete to a far greater extent $(87 \%)$ than those who attend vocational studies $(60 \%)$. 
The group of students defined as dropout is divided in three groups in the Norwegian statistics. The first group of students consists of those who need more time to finish their upper secondary education. If we increase the time interval to 10 years, another $10 \%$ of the students will have successfully completed. The second group consists of students that complete but receive failing grades in one or more of their exams or vocational tests. The third group is students who choose to finish school before they have successfully completed upper secondary education. Based on these different group characteristics, it seems reasonable to consider dropout from upper secondary school as a multifaceted phenomenon with partly different explanatory mechanisms. In the following we will review the research literature on the factors that most researchers seem to agree upon.

\section{Review of factors predicting dropout from upper secondary school}

The research in this article is anchored in an ecological understanding of human development (Bronfenbrenner 1979; Steinberg and Morris 2001), and based on a theoretical understanding of dropout as a process that culminates in the students' decision to leave school (Rumberger 2011; Rumberger and Rotermund 2012). From this perspective, the decision to leave school is the result of an interplay between individual and institutional factors. Individual aspects are associated with the students' behaviour, emotions and cognitions. Institutional aspects are situated in three major contexts-families, schools and communities, and the several key features within them: composition, structure, resources and practices. These are appraised as possible protective factors and/or risk factors that are crucial to gain insight in order to understand the dropout process (Finn 1989; Tinto 1993). Here, we need to study the phases prior to actually leaving school early. By mapping relevant factors and finding effective measures to reduce them, it is possible to be proactive through specific research-based interventions when approaching the problem.

\subsection{Background and home environment}

The student's grades from elementary school have been interpreted as the single most important variable in explaining dropout from upper secondary school (Casillas et al. 2012; Lamb et al. 2010). Norwegian students' grade point average (GPA) is calculated at the end of their elementary education by summing up the grades (in scales from 1 to 6 ), dividing them by the number of grades, and multiplying by 10. Norwegian statistics (2018) show that $99 \%$ of the students with a GPA of 55 or higher completed upper secondary school. In comparison, only $13 \%$ of the students with a GPA of 25 or lower completed upper secondary school. Research controlled for other factors also found that an increase in a GPA of 10 enhances the probability of completing upper secondary school by almost 30\% (Falch et al. 2010).

Both internationally (De Witte et al. 2013; Lamb et al. 2010), and in the Norwegian context (Halvorsrud 2017; Markussen et al. 2011), research indicates that those who succeed in completing upper secondary school have a higher socio-economic 
background compared with those who do not succeed. Low levels of parental education, a low level of family income and living in a single-parent household are all contextual factors that predict dropout from upper secondary school. Only $49 \%$ of the students whose parents have lower secondary school as their highest educational level complete upper secondary school. In comparison, $88 \%$ of the students whose parents have more than 4 years of higher education after lower secondary school reached attainment (Statistics Norway 2018). Halvorsrud (2017) explains this in light of a theory of social reproduction (Boudon 1974; Bourdieu and Passeron 1977), as he argues that the educational system favours values in the middle class over those in the working class, and that the value of education is communicated differently to children depending on their parents' socio-economic position.

Related to family background, research on the significance of parental support has shown that this is a factor that most scholars have agreed upon (Cooper et al. 2005; Englund et al. 2008). Parents' involvement in learning activities at home like helping with homework and communicating regularly seems important for students' attainment (Hill and Tyson 2009; Jeynes 2012). In addition, parents have been identified as potential assets for promoting graduation due to their role as socializing agents, resource providers and guidance across their children's ecological systems (Halvorsrud 2017; Zaff et al. 2017). Parental support seems crucial when it comes to providing access to other key contexts including peers and spare time activities, in addition to providing a safe, caring and stimulating home environment (Fall and Roberts 2012; Rueger et al. 2010). In sum, the students' background and home environment seem crucial when it comes to understanding the dropout process. However, other research has demonstrated that the school environment is another important predictor.

\subsection{Engagement and school environment}

The students' school engagement is a central factor in current research on dropout from upper secondary school (Archambault et al. 2009; Schernoff and Bempechat 2014). In their literature review, Fredricks et al. (2004) identified three different dimensions of school engagement: behavioural, which draws on the idea of participation and effort; emotional, that encompasses affective reactions to school and influence willingness to do the work; and cognitive, that they define as "(...) flexibility in problem solving, preference for hard work, and positive coping in the face of failure" (p. 64). Even though these dimensions can be separated, the components seem to be interrelated (Appleton et al. 2008; Wang and Holcombe 2010). Students who report high levels in all three different types of school engagement are significantly less likely to drop out of upper secondary school and more likely to succeed academically (Stearns et al. 2007; Wang and Eccles 2012). Research has shown that students' experience of the goal orientation at school and support from teachers and peers are important factors to understand the dropout process at it affects such school engagement (Diseth and Samdal 2015; Wang and Eccles 2012).

The goal structure in the classroom is a key factor when it comes to predicting dropout from upper secondary school (Patrick et al. 2011; Wang and Holcombe 
2010). In the prevailing literature (Ames 1992; Meece et al. 2006), goal structure is usually divided in two categories: performance oriented and mastery oriented. In a performance goal structure, learning is predominantly perceived as a means to achieve recognition of worth and extrinsic rewards. Tests and results are emphasized, and success is indicated by outperforming others or surpassing normative standards. The evaluation is public and interpreted in terms of students' relative performance. A mastery goal structure is by comparison more oriented towards the students' real learning and understanding. Success is considered by evaluating effort and indicated by personal improvement.

Teacher support has also been found to be important. Both international and Norwegian reviews conclude that students' close and caring relationship with teachers will prevent dropout (Cornelius-White 2007; Krane et al. 2016). In contrast, negative relationships between teachers and students have been found to predict dropout from upper secondary school (Fortin et al. 2013; Lessard et al. 2014). The influence of having a supportive and respectful relationship with the teachers, and the students' ability to talk with teachers about both personal and academic issues has a significant effect on their continued enrolment (Barile et al. 2012; Wang and Fredericks 2014). In addition to teacher support, social support from peers and friends at school exerts a protective factor against the propensity of dropping out (Terry 2008; Wood et al. 2017). Research findings suggest that "being popular, having friends, and feeling part of the school community can be strong mediating factors" (Frostad et al. 2014: 111).

The literature review indicates that dropout is a lengthy process that is characterized by a gradual loss of school engagement. This process is affected by individual factors, background and home environment and the social and academic environment at the school. In this study, we used the students' intention to leave school as the dependent variable. The literature review yielded a set of predictors and formed the basis for the development of the following hypotheses. The students' intentions to leave upper secondary school will be predicted by their:

1. ... gender, parental education level and academic achievement (Halvorsrud 2017; Lamb et al. 2010)

2. ... experience of parental support (Cooper et al. 2005; Englund et al. 2008).

3. ... experience of teacher support and goal structure at the school (Krane et al. 2016; Patrick et al. 2011; Wang and Holcombe 2010)

4. ... school engagement (Archambault et al. 2009; Schernoff and Bempechat 2014)

5. ... experience of social participation (Frostad et al. 2014; Wood et al. 2017)

In the present study, the social dimensions surrounding the dropout-process will be emphasized more extensively than previous research. These dimensions are explored together with other known factors to scrutinize the relative significance and impact on the students' intentions to leave to a further degree than other studies. In addition, most of the earlier studies are cross-sectional studies, and our longitudinal study reports how the dropout-process evolves over time. In the following our methods are explained more in depth. 


\section{Methods}

The sample for this study comprises 1695 students from upper secondary schools in the county of Trøndelag in Norway and can be described as a convenience sample (McQueen and Knussen 2006). Data were gathered at two different time points, first in autumn 2015 when the students had just started their first year, and second in the spring of 2017 when the students were at the end of their second year of upper secondary school. In 2015 (T1), from the original sample of 2918 students, 2507 answered the questionnaire: a response rate of $86 \%$. Of the 2918 students participating in T1, 1695 students also answered the questionnaire in 2017 (T2), leaving the total response rate at 58\%.

The participating students were informed in advance that participation in the study was voluntary and that they were considered to have given their consent by filling in the questionnaire. The data were collected with paper-based questionnaires and administrated by members of the research team according to the guidelines of the Norwegian Social Data Services. The Norwegian Data Inspectorate approved the survey.

\subsection{Instruments}

\subsubsection{Dependent variable}

The dependent variable Intention to leave was measured with five statements (Vallerand et al. 1992; Valås 1999). The statements address students' thoughts about losing interest and motivation for schoolwork and about leaving school. Examples of these are "I often consider leaving this school", "I am considering leaving school and start working to earn money". Students were invited to indicate on a six-point scale ranging from "absolutely not true" (1) to "absolutely true" (6) to what degree each of the five statements applied to them. After adding the scores, we divided the sum by the number of statements, making the range of the scale 1-6. The same procedure was used when we computed the independent variable scales. In this study, the reliability (Cronbach's alpha) of the scale was .77 for the 2015 sample, and .80 for the 2017 sample.

\subsubsection{Independent variables from hypothesis 1}

Gender was measured by dividing between boys and girls. The scale parental educational level was based on the PISA questionnaire regarding Mother's highest education level (Lundetræ 2011; OECD 2009). The scale was measured with a five-point scale, with the lowest level being elementary school and the highest being more than 3 years of university education. Academic achievement was measured as Grades (GPA) from register data with a range from 10 to 60 . 


\subsubsection{Independent variable from hypothesis 2}

The scale for Parental support was constructed using six statements with a six-point scale that expresses whether the students perceive their parents as being supportive. The statements are based on a scale developed by Malecki and Demary (2002). Examples are: "My parents support me if I have problems", "My parents are interested in my schoolwork". The range of the scale is $1-6$, and the reliability of the scale was .90 for the 2015 sample, and .91 for the 2017 sample.

\subsubsection{Independent variables from hypothesis 3}

The prevailing research literature discusses whether Teacher support should be described as a multidimensional phenomenon or by a single underlying quality (Downer et al. 2015). For instance, Pianta et al. (2010) suggest dividing the concept in three: emotional support, academic support and classroom organization. In line with this, we constructed two scales; one for emotional support and one for academic support from the teacher. Both the scales consisted of four statements with a six-point scale based on Malecki and Demary (2002). Examples of statements: "I feel that my teachers care about me", "I feel that my teachers treat me in a friendly manner" (emotional support), and "The teachers explain what I don't understand", "My teachers continue to explain until I understand" (academic support). However, a factor analysis showed a single factor structure. Based on this, we developed one scale for teacher support based on all 8 statements. The scale has a range from 1-6 and the internal consistency was high, .91 (2015) and .93 (2017).

The measurement of goal structure was based on Midgley et al.'s (2000) operationalization of the concept. We divided this into two variables: Mastery oriented and Performance oriented, with four statements for each scale. Examples of statements: "What matters in our class is that we do the best that we can when working with the subject matter", "It is OK to make mistakes in class as long as you learn from them" (mastery oriented). "The most important thing in our class is to get good grades", "The most important thing in our class is to perform well in school" (performance oriented). The range from both the scales was $1-6$ and reliability was high for both scales: mastery oriented (.67 in 2015 and .70 in 2017), performance oriented (.89 in 2015 and .87 in 2017).

\subsubsection{Independent variables from hypothesis 4}

The students' school engagement was in line with Fredericks et al. (2004) operationalized and consisted of behavioural, emotional and cognitive dimensions.

School engagement connected to the behavioural dimensions was measured as Effort in the school work with four statements. Three of the statements express that the students are working hard with the subject matter, and one the opposite. The last statement was turned before we made the scale. Examples of statements: "I work well with the tasks we get at school", "I'm paying attention during the lectures at school". The range of scale was 1-6, and the reliability was high with .79 both in 2015 and in 2017. 
Emotional school engagement was measured as Intrinsic motivation, with four statements based on Deci and Ryan's (1985) and Vallerand et al.'s (1992) scales. Examples of statements: "I think it is fun to work with the subject matter", "The subject matter at school interests me". The range of the scale was 1-6, and the internal consistency was high with .86 in 2015 and .91 in 2017.

The cognitive school engagement was measured as the students' Coping ability when facing adversity in the school work. We based our measurement on Schroder and Ollis' (2013) Coping Competence Questionnaire. This instrument had originally 12 statements, and we used the 5 statements with the highest loadings from the factor analysis. All the statements are formulated negatively and were turned before we made the scale. Examples of statements: "When I do not succeed right away, I think I will never get it", "When I perform poorly at school, I begin to doubt my abilities". The range of scale was 1-6, and the reliability was high with .87 both in 2015 and in 2017.

\subsubsection{Independent variable from hypothesis 5}

The students' social participation can be measured in various ways as this may encompass aspects such as peer acceptance or friendships in school. In this project, we are measuring the students' experience of Loneliness, as an indicator of their social participation. Loneliness can be understood as the result of the discrepancy between one's desired and actual relationships (Frostad et al. 2015; Peplau and Perlman 1982). We based our scale on the modified Norwegian version of the Loneliness and Social Dissatisfaction Questionnaire (Asher and Wheeler 1985; Valås 1999). The students were asked to respond to five statements. Examples of statements: "I have no one to be together with at school", "I feel like an outsider in school". In the same manner as with the previously described sum score scales, the students were invited to indicate how far each of these statements applied to them on a six-point Likert scale, ranging for "absolutely not true" to "absolutely true". The range of the scale was 1-6, and Cronbach's alpha for the scale was .83 in 2015 and .90 in 2017.

\subsection{Analysis}

To ensure the validity of the scales we initially ran exploratory factor analyses. This was followed by a descriptive analysis of all the variables, before we finally placed the set of predictors from the hypotheses in a hierarchical regression model (Wampold and Freund 1987). In the stepwise causal modelling, the independent variables were placed in the same order as the hypotheses are formulated. In this way we were able to test how much of the variance in the dependent variable each of the independent variables explained, beyond those entered in the previous steps. 


\section{Results}

The exploratory factor analysis was conducted by using Oblimin rotation and consisted of 8 sum scales with a total of 40 statements (see Method for details). The analysis gave a clear 8-factor structure where the statements loaded on the expected latent variables. None of the claims had loadings over .30 on the unexpected variables. With the exception of one $.53, .60$ or higher. The 8 factors explained $66 \%$ of the variance in the 40 statements in 2015 , and $69 \%$ of the variance in 2017.

Tables 1 (2015) and 2 (2017) display the results of the bivariate correlations between the described variables.

From Tables 1 and 2, we can see that all of the independent variables, except Gender, have a significant correlation with the dependent variable for both of the datasets. Mother's educational level, Grades (GPA), Parental support, Teacher support, Mastery oriented goal structure, Effort, Intrinsic motivation and Coping have a significant negative correlation with the dependent variable for both sets. This implies that students with high values for these variables have low values on the Intention to leave variable. The students' experience of a Performance oriented goal structure in the classroom and Loneliness have positive correlations with the dependent variable. High levels for these variables imply high levels for the Intention to leave variable. Of all the positive and negative correlations between the dependent and independent variables, Loneliness clearly has the strongest connection, with .43 in 2015 and .51 in 2017.

As expected, we find several significant correlations between the independent variables. The highest correlation is between Teacher support and Performance oriented goal structure in the classroom. None of the correlations between the independent variables are as high .80 . This means that we do not have a problem regarding multicollinearity (Field 2013).

Table 3 displays the share of explained variance in the dependent variable, both in 2015 and 2017, for each of the steps in the regression analysis. The first column tells what step/hypothesis that is included in the hierarchical regression and the name of the predictor variables. The second and third columns describe the adjusted $\mathrm{R}^{2}$ for 2015 and 2017, respectively. This is a measure of goodnessof-fit used in the linear regression models. The fourth and fifth columns describe the standardized regression coefficients (Beta) that enable comparisons of variables that are measured in the different units (Hamilton 1992), for 2015 and 2017, respectively.

Table 3 shows that the independent variables connected to the first hypothesis explained 3.4\% (2015) and 4.3\% (2017) of the variance of the students' Intention to leave upper secondary school. In the second step we added Parental support. This variable explained another $12.8 \%$ (2015) and $13.6 \%$ (2017) of the variance. The variables connected to the third hypothesis contributed with another $7.1 \%$ (2015) and 7.4\% (2017) explained variance, and the variables connected to school engagement in the fourth step explained $7.1 \%$ (2015) and $10 \%$ (2017) of the variance. At the end we see that the independent variable Loneliness explains $7.7 \%$ 


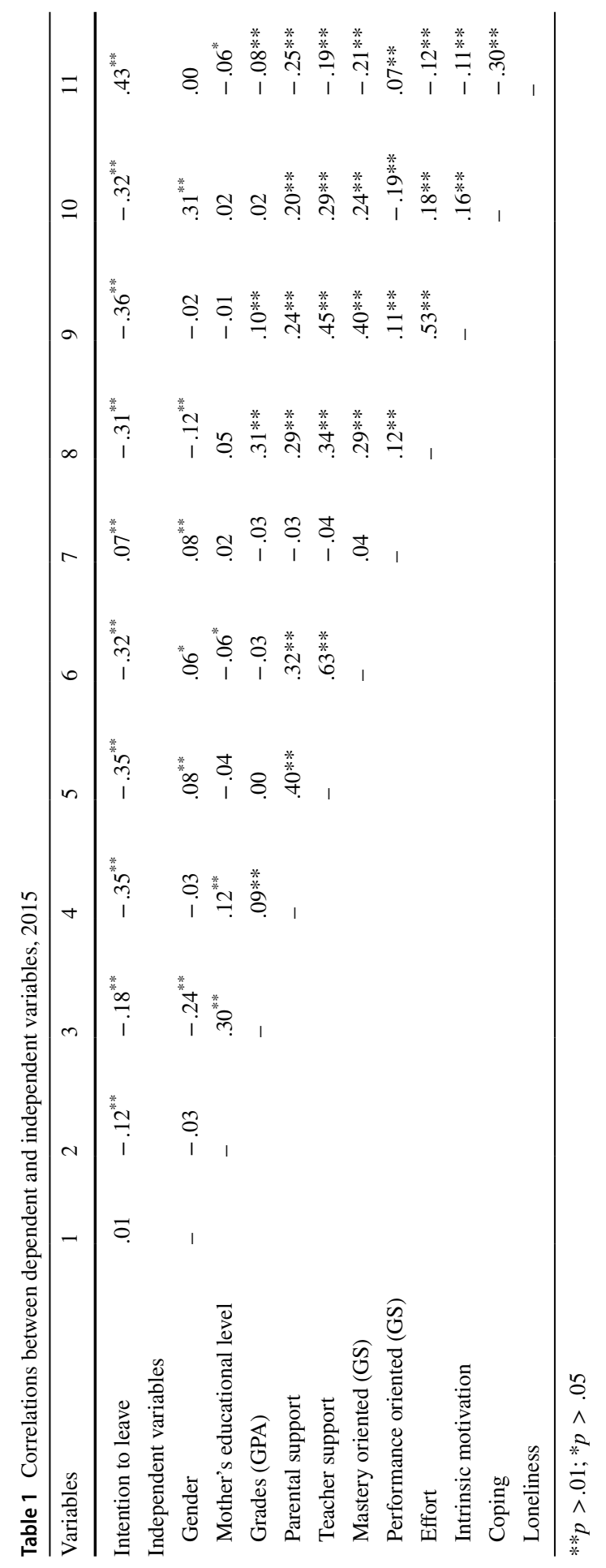




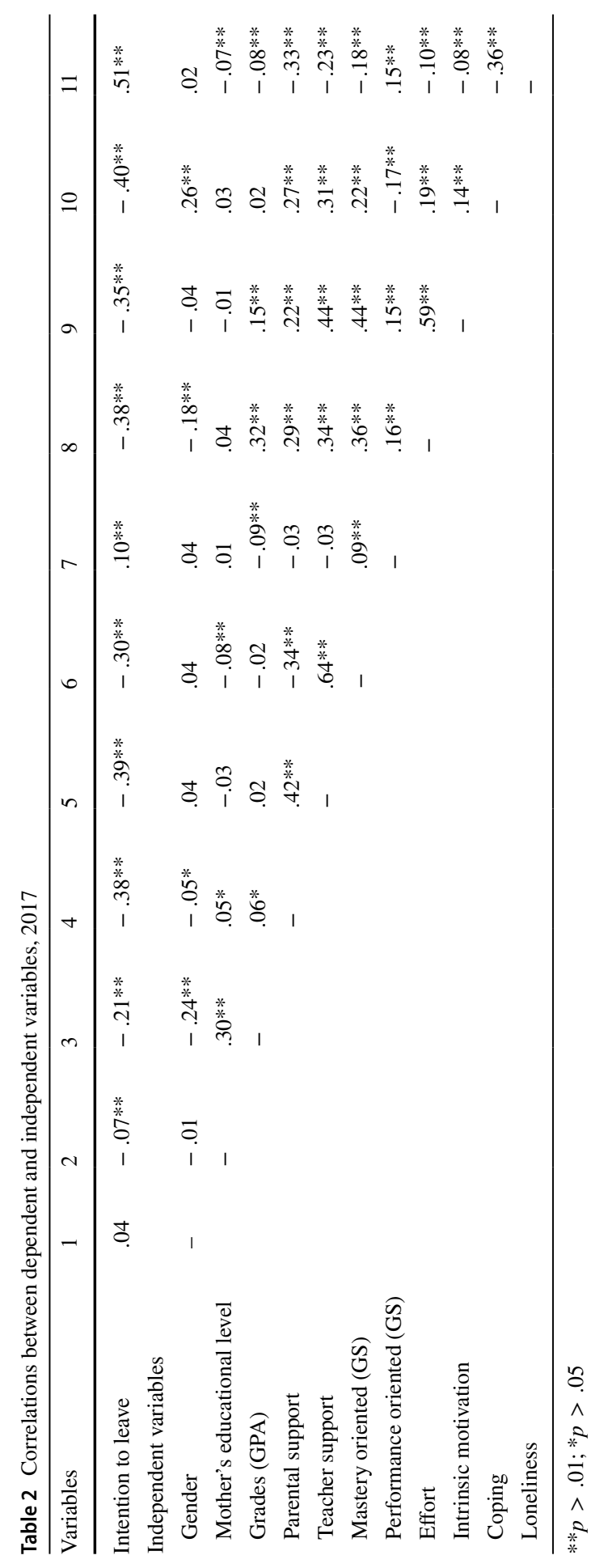




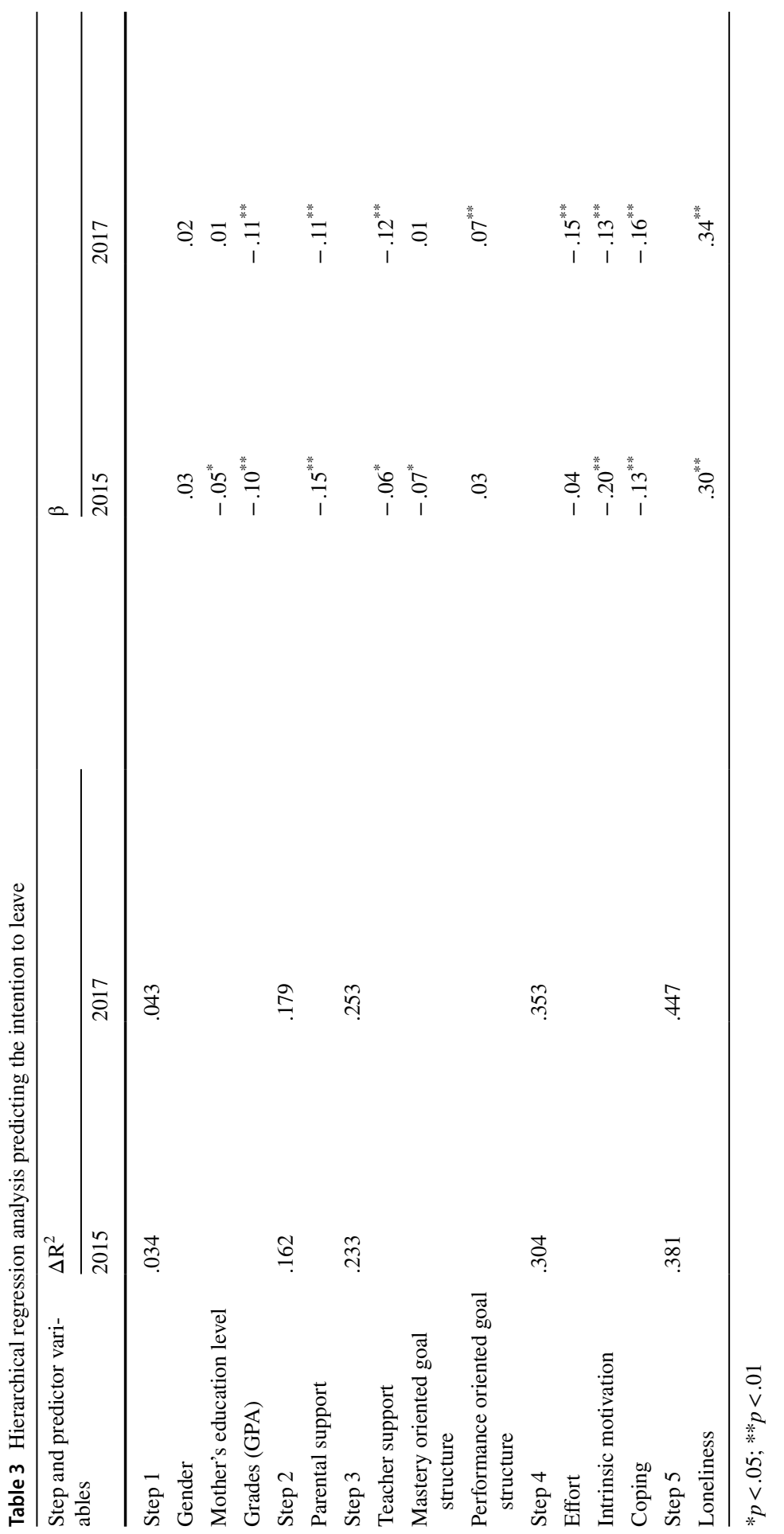


(2015) and 9.4\% (2017) alone. With all the independent variables placed in the model, we explain $38.1 \%$ (2015) and $44.7 \%$ (2017) of the variance in the students' Intentions to leave upper secondary school.

Table 3 also shows the standardized regression coefficients when all the variables were added. These coefficients are the contribution of each of the independent variables, controlled for the contribution from the others. Because of this, we see that the numbers depart from the bivariate correlations, and that some of the independent variables no longer provide significant contributions when it comes to explain the students' intention to leave upper seconday school. As such, this analysis provides a basis for determining which of the independent factors are relatively the most important.

Furthermore, Table 3 shows that 8 of the 11 factors that were measured in 2015 provide significant contributions. Grades are important, but Parental support, Intrinsic motivation and Coping seem to have a stronger impact. Also, 8 of the 11 factors also provide significant contributions in 2017. However, these are not the same as in 2015. We see that Mother's education level and the students experience of a Mastery oriented goal structure no longer have a significant impact, and that a Performance oriented goal structure and the students' self-reported Effort from 2015 to 2017 evolves from not playing a major role to become significant predictors for the students Intentions to leave school. Even so, the main finding is that it is the experience of Loneliness among students is the strongest predictor, both in 2015 (.30) and in 2017 (.34).

\section{Discussion}

The research in this study sought to map factors that predict Norwegian students' intentions to leave upper secondary school. In this article we have reported findings connected to how the significance and impact of different factors changes during the first 2 years of upper secondary school. Dropout has been studied as the final culmination of a long process and in the project we illuminated factors on both the individual and institutional levels.

It is important to underline and be aware of the fact that we have measured the Intention to leave, and not the actual dropout decision. Although research suggests that there are clear connections between intentions and actions in this area (Freeney and O'Connell 2012), it will nevertheless be possible that students may choose to stay in school even if they have strong wishes to leave. In his theory of planned behaviour, Ajzen (1991) explains that several conditions determine whether the intended action will be realized in actual action. First, the individual's perception of the consequences of the action will be important. Second, there is the individual's perception of the act itself. Furthermore, the perception of social norms will be significant, and finally the individual's locus of control connected to the actions will be of great importance. This study does not provide grounds for drawing conclusions regarding the causality between the independent variables and the intentions to leave upper secondary school. Even still, the influence that has been found may provide 
grounds for reflection when it comes to the schools preventive work connected to dropout.

Previous research (Halvorsrud 2017; Lamb et al. 2010), has shown that the academic performance (measured as grades (GPA)) from elementary school is the most important factor when it comes to explain dropout from upper secondary school. In line with this, we find that grades from elementary school have a considerable impact. We regard this as an expected finding. As research shows that boys are leaving upper seconday school to a much higher degree than girls (De Witte et al. 2013; Markussen et al. 2011), it is more surprising that this factor does not seem to have a significant impact when it comes to the students' intentions to leave school in our sample. However, when we dig deeper in the research literature, we see that the relatively larger dropout proportion of boys compared to girls correlates to a high degree with structural conditions at a later stage of the education (especially the transition from school to apprenticeship in the vocational programmes) (Vogt 2008, 2017). Statistics from the same region as we gathered the data from reveal that $4.3 \%$ of the boys and $5.0 \%$ of the girls leave during the first year of upper secondary school. Our study and registry data concerning actual dropout rates thus confirm that dropout during the first year does not seem to have a gender dimension.

Another surprising finding is that mother's educational level did not have a significant impact on the students' intention to leave. This is in distinct contrast to other research findings (De Witte et al. 2013; Halvorsrud 2017). However, parental support did stand out as a factor that correlates negatively with the dependent variable. It could be that mother's educational level as a factor is affected by the effect of the students' perception of parental support. Based on this, it seems important that this is being conveyed from the school to the parents, so that the preventive work against dropout becomes a joint effort in the school-home collaboration.

All of the three school variables seem to be have a significant impact on the dependent variable. Teacher support is especially a factor that is worth considering. This factor seems to be more significant and has more impact as the students continue to attend upper secondary school. In our sample we did not find different dimensions in this variable. This may be due to the way we measured it, but also due to the fact that the students do not differentiate between different forms of support from their teacher. Students may simply experience their teacher as either a supportive or a non-supportive person. However, theoretically it is interesting to distinguish between emotional and professional support. We need additional research on this matter to get more knowledge on exactly how the different types of support affect the intentions to leave.

In addition to teacher support, we also found that the goal structure in the classroom had an effect. The correlational analysis shows that students that to a lesser extent perceive a mastery oriented goal structure lead to more pressing intentions to leave compared to those who perceive that there is a performance oriented goal structure. The same tendency is expressed in the hierarchical regression model, and we see that the negative effect of a performance oriented goal structure is strengthened from the first year to the second year of upper secondary school. Based on this, there may be reason to consider whether the strong emphasis on performance and comparison that we find in schools today (Falch et al. 2016; Sjøberg 2015), 
stimulates teachers towards performance orientation to a greater degree than a mastery orientation in their classrooms. If that is the case, the goal structure may also affect the students' school engagement, for example their intrinsic motivation (Skaalvik and Skaalvik 2013), effort (Wolters 2004), sense of belonging (Walker 2012), and positive relationships with fellow students and teachers (Polychroni et al. 2012). These are all factors that may influence the students' intentions to leave upper secondary school.

We found that all of the three variables that were intended to measure the students' school engagement had a significant effect on the dependent variable. Effort, intrinsic motivation and coping have a clear connection with the intention to leave in the bivariate analysis. The hierarchical regression model indicates that these effects are strengthened from the first to second years of upper secondary school. In the final model from 2017 we see that it is the students' coping competence that has the strongest impact of the three. As far as we know, there has not been any research on how students' ability to cope with adversity can affect the dropout process. We believe that this is a finding to note. Can the school do something to influence such competence? We know that girls in this age group report considerable amounts of mental health problems (Bor et al. 2014; Holen et al. 2017), and we need more research to investigate whether this may be due to focusing on problems in favour of problem-solving skills and the development of coping competence in this age group.

\subsection{Limitations, future directions, and practical implications}

The data in this project build on the students' subjective perceptions of factors in school. We can question whether this presents a valid description of what we have labelled as institutional variables. We may have seen different results if we had mapped the learning environment by describing structures, content and teaching more descriptively. However, the intention of this project was based on the student perspective. It is the students that perceive the school. The school structure and the teachers' intentions are not necessarily perceived equally by all, and it is the students' experience that ultimately will lead to whether they choose to stay or choose to leave upper secondary school.

Our research supports the ideas behind interventions that focus on training teachers how to support the emotional needs and educational aspirations of adolescents (Fall and Roberts 2012; Zaff et al. 2017). In addition, we need interventions aimed at impacting how the students are interacting with each other (Feinberg et al. 2007; Sancassiani et al. 2015). Of all the investigated predictive factors in our study, we found that loneliness both had the strongest correlation and explained most of the variance in the regression model. This effect was even strengthened from 2015 to 2017. Loneliness has been proved to be an important explanation for the students' intention to leave upper secondary school in other studies (Frostad et al. 2015; Mjaavatn and Frostad 2014), and the validity of this finding is thus strengthened. Fortunately, more attention has been paid to social relationships between students in school, and the effects of socio-emotional learning in schools shows promising results (Durlak et al. 2011; Taylor et al. 2017). Several intervention programmes are 
now being tested in Norway (Andersen 2016; Holen et al. 2012). The results from the project reported in this article indicates that this is an important focus area in efforts to reduce dropout from upper secondary school.

\section{Conclusion}

This longitudinal study has illuminated the relative impact of individual and institutional factors on the students' decision to leave school. The sample was comprised of 1695 students from upper secondary school in the county of Trøndelag in Norway. Our findings from the descriptive analysis, correlations and hierarchical regression shows that the students' grades from elementary school, parental and teacher support, school engagement and coping competence in upper secondary school are important explanatory factors leading to dropout. Loneliness at secondary school seems to be the most important predictive factor in relation to the students' thoughts about leaving. This suggest that we need to scrutinize the social dimensions surrounding the dropout-process more in depth to improve prevention efforts in the future. Teachers, counsellors and the school as a whole should increase their efforts to facilitate the development of support and relationships between peers as this seems to be both a decisive protective factor and risk factor when it comes to prevent dropout.

\section{Compliance with ethical standards}

Conflict of interest The authors declares that they have no conflict of interest.

Ethical approval The study was approved by the The Norwegian Data Inspectorate.

Informed consent Informed consent was obtained from all participants. Additionally, parents were sent an informational letter with the option to opt their child out of the study.

Open Access This article is distributed under the terms of the Creative Commons Attribution 4.0 International License (http://creativecommons.org/licenses/by/4.0/), which permits unrestricted use, distribution, and reproduction in any medium, provided you give appropriate credit to the original author(s) and the source, provide a link to the Creative Commons license, and indicate if changes were made.

\section{References}

Ajzen, I. (1991). The theory of planned behavior. Organizational Behavior and Human Decision Processes, 50(2), 179-211. https://doi.org/10.1016/0749-5978(91)90020-T.

Ames, C. (1992). Classrooms: Goals, structures, and student motivation. Journal of Educational Psychology, 84, 261-271. https://doi.org/10.1037/0022-0663.84.3.261.

Andersen, B. J. (2016). Informasjon om psykisk helse - et sentralt tiltak for å fremme elevers sosiale og emosjonelle kompetanse. [Information about mental health - a central measure to promote pupils 
social and emotional competence]. In E. Bru, E. C. Idsøe, \& K. Øverland (Eds.), Psykisk helse $i$ skolen (pp. 257-270). Oslo: Universitetsforlaget.

Appleton, J. J., Christenson, S. L., \& Furlong, M. J. (2008). Student engagement with school: Critical conceptual and methodological issues of the concept. Psychology in the Schools, 45, 369-386. https ://doi.org/10.1016/j.jsp.2006.04.002.

Archambault, I., Janosz, M., Fallu, J.-S., \& Pagani, L. S. (2009). Student engagement and its relationship with early high school dropout. Journal of Adolescence, 32, 651-670. https://doi.org/10.1016/j. adolescence.2008.06.007.

Asher, S. R., \& Wheeler, V. A. (1985). Children's loneliness: A comparison of rejected and neglected peer status. Journal of Consulting and Clinical Psychology, 53, 500-505. https://doi. org/10.1037/0022-006X.53.4.500.

Barile, J. P., Donohue, D. K., Anthony, E. R., Baker, A. M., Weaver, S. R., \& Henrich, C. C. (2012). Teacher-student relationship climate and school outcomes: Implications for educational policy initiatives. Journal of Youth and Adolescence, 41, 256-267. https://doi.org/10.1007/s10964-011-9652-8.

Bor, W., Dean, A. J., Najman, J., \& Hayatbakhsh, R. (2014). Are child and adolescent mental health problems increasing in the 21st century? A systematic review. Australian and New Zealand Journal of Psychiatry, 48(7), 606-616. https://doi.org/10.1177/0004867414533834.

Boudon, R. (1974). Education, Opportunity, and Social Inequality: Challenging prospects in western society. London: Wiley.

Bourdieu, P., \& Passeron, J.-C. (1977). Reproduction in education, society and culture. London: Sage Publications.

Bronfenbrenner, U. (1979). The ecology of human development. Cambridge, MA: Harvard University Press.

Casillas, A., Robbins, S., Allen, J., Kuo, Y.-L., Hanson, M. A., \& Schmeiser, C. (2012). Predicting early academic failure in high school from prior academic achievement, psychosocial characteristics, and behavior. Journal of Educational Psychology, 104(2), 407-420. https://doi.org/10.1037/a0027180.

Cooper, C. R., Chavira, G., \& Mena, D. D. (2005). From pipelines to partnerships: A synthesis of research on how diverse families, schools, and communities support children's pathways through school. Journal of Education for Students Placed at Risk, 10(4), 407-430. https://doi.org/10.1207/ s15327671espr1004_4.

Cornelius-White, J. (2007). Learner-centered teacher-student relationships are effective: A meta-analysis. Review of Educational Research, 77(1), 113-143. https://doi.org/10.3102/003465430298563.

De Ridder, K. A., Pape, K., Johnsen, R., Westin, S., Holmen, T. L., \& Bjorngaard, J. H. (2012). School dropout: A major public health challenge: A 10-year prospective study on medical and non-medical social insurance benefits in young adulthood, the Young-HUNT 1 Study (Norway). Journal of Epidemiology and Community Heath, 66(11), 995-1000. https://doi.org/10.1136/jech-2011-200047.

De Witte, K., Cabus, S., Thyssen, G., Groot, W., \& van den Brink, H. M. (2013). A critical review of the literature on school dropout. Educational Research Review, 10, 13-28. https://doi.org/10.1016/j. edurev.2013.05.002.

Deci, E. L., \& Ryan, R. M. (1985). Intrinsic motivation and self-determination in human behavior. New York, NY: Plenum.

Diseth, A., \& Samdal, O. (2015). Classroom achievement goal structure, school engagement, and substance use among 10th grade students in Norway. International Journal of School and Educational Psychology, 3(4), 267-277. https://doi.org/10.1080/21683603.2015.1084250.

Downer, J. T., Stuhlman, M., Schweig, J., Martinez, J. F., \& Ruzek, E. (2015). Measuring effective teacher-student interactions from a student perspective: A multi-level analysis. Journal of Early Adolescence, 35(5-6), 722-758. https://doi.org/10.1177/0272431614564059.

Durlak, J. A., Weissberg, R. P., Dymnicki, A. B., Taylor, R. D., \& Schellinger, K. B. (2011). The impact of enhancing students' social and emotional learning: A meta-analysis of school-based universal interventions. Child Development, 82(1), 405-432. https://doi.org/10.1111/j.1467-8624.2010.01564 .X.

Englund, M. M., Egeland, B., \& Collins, W. A. (2008). Exceptions to high school dropout predictions in a low-income sample. Do adults make a difference? Journal of Social Issues, 64, 77-94. https://doi. org/10.1111/j.1540-4560.2008.00549.x.

Falch, T., Bensnes, S., \& Strøm, B. (2016). Skolekvalitet i videregående opplæring. Utarbeidelse av skolebidragsindikatorer og mål på skolekvalitet. [School quality in upper secondary education. Preparation of school contribution indicators and school quality objectives]. Senter for Økonomisk Forskning. Rapport nr. 01/16. 
Falch, T., Borge, L.-E., Päivi, L., Nyhus, O. H., \& Strøm, B. (2010). Årsaker til og konsekvenser av manglende fullføring av videregående opplaring. [Reasons for and consequences of failure to complete upper secondary education]. Senter for Økonomisk Forskning. Rapport nr. 03/10.

Falch, T., Johannessen, A. B., \& Strøm, B. (2009). Kostnader av frafall $i$ videregående opplaring. [Costs of dropout from upper secondary education]. Senter for Økonomisk Forskning.

Fall, A. M., \& Roberts, G. (2012). High school dropouts: Interaction between social context, self-perceptions, school engagement, and student dropout. Journal of Adolescence, 35, 787-798. https://doi. org/10.1016/j.adolescence.2011.11.004.

Feinberg, M. E., Greenberg, M. T., Osgoode, D. W., Sartorius, J., \& Bontempo, D. (2007). Effects of the communities that care model in Pennsylvania on youth risk and problem behaviors. Prevention Science, 8, 261-270. https://doi.org/10.1007/s11121-007-0073-6.

Field, A. (2013). Discovering statistics using IBM SPSS statistics (4th ed.). London: Sage.

Finn, J. (1989). Withdrawing from school. Review of Educational Research, 59, 117-142. https://doi. org/10.3102/00346543059002117.

Fortin, L., Marcotte, D., Diallo, T., Potvin, P., \& Royer, E. (2013). A multidimensional model of school dropout from an 8-year longitudinal study in a general high school population. European Journal of Psychology of Education, 28(2), 563-583. https://doi.org/10.3102/003465430298563.

Fredrichs, J. A., Blumenfeld, P. C., \& Paris, A. H. (2004). School engagement: Potential of the concept, state of the evidence. Review of Educational Research, 74, 59-109. https://doi.org/10.3102/00346 543074001059.

Freeney, Y., \& O'Connell, M. (2012). The predictors of the intention to leave school early among a representative sample of Irish second-level students. British Educational Research Journal, 38(4), 557574. https://doi.org/10.1080/01411926.2011.563838.

Frostad, P., Pijl, S. J., \& Mjaavatn, P. E. (2014). Losing all interest in school: Social participation as a predictor of the intention to leave upper secondary school early. Scandinavian Journal of Educational Research, 59(1), 110-122. https://doi.org/10.1080/00313831.2014.904420.

Frostad, P., Pijl, S. J., \& Mjaavatn, P. E. (2015). Losing all interest in school: Social participation as a predictor of the intention to leave upper secondary school early. Scandinavian Journal of Educational Research, 59(1), 110-122. https://doi.org/10.1080/00313831.2014.904420.

Halvorsrud, K. (2017). Student dropout in upper secondary education in Norway: A challenge to the principles of the welfare state? London Review of Education, 15(2), 302-316. https://doi.org/10.18546/ LRE.15.2.12.

Hamilton, L. C. (1992). Regression with graphics: A second course in applied statistics. California, CA: Wadsworth Inc.

Hill, N. E., \& Tyson, D. F. (2009). Parental involvement in middle school: A meta-analytic assessment of the strategies that promote achievement. Developmental Psychology, 45, 740-763. https://doi. org/10.1037/a0015362.

Holen, S., Waaktaar, T., Lervåg, A., \& Ystgaard, M. (2012). The effectiveness of a universal schoolbased programme on coping and mental health: A randomised, controlled study of Zippy's friends. Educational Psychology, 32(5), 657-677. https://doi.org/10.1080/01443410.2012.686152.

Holen, S., Waaktaar, T., \& Sagatun, A. (2017). A chance lost in the prevention of school dropout? Teacher-student relationships mediate the effect of mental health problems on noncompletion of upper secondary school. Scandinavian Journal of Educational Research, 62, 1-17. https://doi. org/10.1080/00313831.2017.1306801.

Jeynes, W. (2012). A meta-analysis of the efficacy of different types of parental involvement programs for urban students. Urban Education, 47, 706-742. https://doi.org/10.1177/0042085912445643.

Krane, V., Karlsson, B., Ness, O., \& Kim, H. S. (2016). Teacher-student relationship, student mental health, and dropout from upper secondary school: A literature review. Scandinavian Psychologist, 3, 1-25.

Lamb, S., Markussen, E., Teese, R., Sandberg, N., \& Polesel, J. (2010). School dropout and completion: International comparative studies in theory and policy. Dordrecht: Springer.

Lessard, A., Butler-Kisber, L., Fortin, L., \& Marcotte, D. (2014). Analyzing the discourse of dropouts and resilient students. The Journal of Educational Research, 107(2), 103-110. https://doi. org/10.1080/00220671.2012.753857.

Lundetræ, K. (2011). Does parental educational level predict drop-out from upper secondary school for 16- to 24-year-olds when basic skills are accounted for? A cross-country comparison. Scandinavian Journal of Educational Research, 55(6), 625-637. https://doi.org/10.1080/00313831.2011.555925. 
Malecki, C. K., \& Demary, M. C. (2002). Measuring perceived social support: Development of the Child and Adolescent Social Support Scale (CASS). Psychology in the Schools, 39(1), 1-18. https://doi. org/10.1002/pits.10004.

Markussen, E., Frøseth, M. W., \& Sandberg, N. (2011). Reaching for the unreachable: Identifying factors predicting early school leaving and non-completion in Norwegian upper secondary school. Scandinavian Journal of Educational Research, 55(3), 225-253. https://doi.org/10.1080/00313 831.2011.576876.

McQueen, R. A., \& Knussen, C. (2006). Introduction to research methods and statistics in psychology. Harlow: Pearson.

Meece, J. L., Anderman, E. M., \& Anderman, L. H. (2006). Classroom goal structure, student motivation and academic achievement. Annual Review of Psychology, 57, 487-503. https://doi.org/10.1146/annur ev.psych.56.091103.070258.

Midgley, C., Maehr, M. L., Hruda, L. Z., Anderman, E., Anderman, L., Freeman, K. E., et al. (2000). Manual for the patterns of adaptive learning scales. Michigan, MA: Universtity of Michigan.

Mjaavatn, P. E., \& Frostad, P. (2014). Tanker om å slutte på videregående skole. Er ensomhet en viktig faktor? [Thoughts about leaving upper secondary school. Is lonelines an important factor?]. Spesialpedagogikk, 1, 47-55.

OECD. (2009). Programme for International Student Assessment, Students questionaire. Paris: OECD.

OECD. (2017). Education at a Glance 2017: OECD INDICATORS. Retrieved from Parus.

Patrick, H., Kaplan, A., \& Ryan, A. M. (2011). Positive classroom motivational environments: Convergence between mastery goal structure and classroom social climate. Journal of Educational Psychology, 103(2), 367-382. https://doi.org/10.1037/a0023311.

Peplau, L., \& Perlman, D. (1982). Loneliness: A sourcebook for current theory, research and therapy. New York, NY: Wiley.

Pianta, R. C., Hamre, B. K., \& Mintz, S. L. (2010). Classroom assessment scoring system manual-upper elementary. Charlottesville: University of Virginia.

Polychroni, F., Hatzichristou, C., \& Sideris, G. (2012). The role of goal orientations and goal structures in explaining classroom social and affective characteristics. Learning and Individual Differences, 22(2), 207-217. https://doi.org/10.1016/j.lindif.2011.10.005.

Rueger, S. Y., Malecki, C. K., \& Demaray, M. K. (2010). Relationship between multiple sources of perceived social support and psychological and academic adjustment in early adolescence: Comparisons across gender. Journal of Youth and Adolescence, 39, 47-61. https://doi.org/10.1007/s10964-008-9368-6.

Rumberger, R. W. (2011). Dropping out. Why students drop out of high school and what can be done about it. Boston, MA: Harvard University Press.

Rumberger, R. W., \& Lamb, S. P. (2003). The early employment and further education experiences of high school dropouts: A comparative study of the United States and Australia. Economics of Education Review, 22(4), 353-366. https://doi.org/10.1016/S0272-7757(02)00038-9.

Rumberger, R. W., \& Rotermund, S. (2012). The relationship betweeen engagement and high school dropout. In S. L. Christenson, A. L. Reschly, \& C. Wylie (Eds.), Handbook of research on student engagement (pp. 491-514). New York, NY: Springer.

Sancassiani, F., Pintus, E., Holte, A., Paulus, P., Moro, M. F., Cossu, G., et al. (2015). Enhancing the emotional and social skills of the youth to promote their wellbeing and positive development: A systematic review of universal school-based randomized controlled trials. Clinical Practice and Epidemiology in Mental Health, 11, 21-40. https://doi.org/10.2174/1745017901511010021.

Schernoff, D. J., \& Bempechat, J. (2014). Introduction to engaging youth in schools, an NSSE Yearbook. National Society for the Study of Education, 113(1), 1-14.

Schroder, K. E. E., \& Ollis, C. L. (2013). The coping competence questionaire: A measure of resilience to helplessness and depression. Motivation and Emotion, 37, 286-302. https://doi.org/10.1007/s1103 1-012-9311-8.

Sjøberg, S. (2015). PISA and global educational governance: A critique of the project, its uses and implications. Euresia Journal of Mathematics, Science and Technology Education, 11(1), 111-127. https://doi. org/10.12973/eurasia.2015.1310a.

Skaalvik, E. M., \& Skaalvik, S. (2013). School goal structure: Associations with student's perceptions of their teachers as emotionally supportive, academic self-concept, intrinsic motivation, effort, and help seeking behavior. International Journal of Educational Research, 61, 5-14. https://doi.org/10.1016/j. ijer.2013.03.007.

Statistics Norway (2018). Gjennomstrømmning $i$ videregående opplaring, 2012-2017. [Throughput in upper secondary education, 2012-2017] URL: https://www.ssb.no/utdanning/statistikker/vgogjen/aar 
Stearns, E., Moller, S., Blau, J., \& Potochnick, S. (2007). Staying back and dropping out: The relationship between grade retention and school dropout. Sociology of Education, 80, 210-240. https://doi. org/10.1177/003804070708000302.

Steinberg, L., \& Morris, A. S. (2001). Adolescents development. Annual Review of Psychology, 52, 83-110. https://doi.org/10.1146/annurev.psych.52.1.83.

Taylor, R. D., Oberle, E., Durlak, J. A., \& Weissberg, R. P. (2017). Promoting positive youth development through school-based social and emotional learning interventions: A meta-analysis of follow-up effects. Child Development, 88(4), 1156-1171. https://doi.org/10.1111/cdev.12864.

Terry, M. (2008). The effects that family members and peers have on students' decisions to drop-out of school. Educational Research Quarterly, 31(3), 25-38.

Tinto, V. (1993). Leaving College: Rethinking the causes and cures of student attrition (2nd ed.). Chicago, IL: University of Chicago Press.

Vallerand, R. J., Pelletier, L. G., Blais, M. R., Briere, N. M., Senecal, C., \& Vallieres, E. F. (1992). The academic motivation scale: A measure of intrinsic, extrinsic, and amotivation in education. Education and Psychological Measurement, 52, 1003-1017.

Valås, H. (1999). Students with learning disabilities and low-achieving students: Peer acceptance, loneliness, self-esteem, and depression. Social Psychology of Education, 3, 173-192. https://doi. org/10.1023/A:1009626828789.

Vogt, K. C. (2008). Er frafall i videregående opplæring et kjønnsproblem? [Is dropout from upper secondary education a gender problem?]. Tidsskrift for samfunnsforskning, 49(4), 517-541.

Vogt, K. C. (2017). Vår utålmodighet med ungdom [Our impatience with young people]. Tidsskrift for samfunnsforskning, 58(1), 105-119. https://doi.org/10.18261/ISSN.1504-291X-2017-01-05.

Walker, C. (2012). Student perceptions of classroom achievement goals as predictors of belonging and content instrumentality. Social Psychology of Education, 15(1), 97-107. https://doi.org/10.1007/s1121 8-011-9165-Z.

Wampold, B. E., \& Freund, R. D. (1987). Use of multiple regression in counseling psychology: A flexible data-analytic strategy. Journal of Counselling Pscyhology, 34(4), 372-382. https://doi. org/10.1037/0022-0167.34.4.372.

Wang, M. T., \& Eccles, J. S. (2012). Social support matters: Longitudinal effects of social support on three dimensions of school engagement from middle to high school. Child Development, 83(3), 877-895. https://doi.org/10.1111/j.1467-8624.2012.01745.x.

Wang, M. T., \& Fredericks, J. (2014). The reciprocal links between school engagement, youth problem behaviors, and school dropout during adolescence. Child Development, 85, 722-737. https://doi. org/10.1111/cdev.12138.

Wang, M. T., \& Holcombe, R. (2010). Adolescents' perceptions of school environment, engagement, and academic achievement in middle school. American Educational Research Journal, 47(3), 633-662. https://doi.org/10.3102/0002831209361209.

Wolters, C. A. (2004). Advancing ahievement goal theory: Using goal structures and goal orientations to predict students' motivation, cognition, and achievement. Journal of Educational Psychology, 96(2), 236-250. https://doi.org/10.1037/0022-0663.96.2.236.

Wood, L., Kiperman, S., Esch, R. C., Leroux, A. J., \& Truscott, S. D. (2017). Predicting dropout using student-and school-level factors: An ecological perspective. School Psychology Quarterly, 32, 35-49. https ://doi.org/10.1037/spq0000152.

Zaff, J. F., Donlan, A., Gunning, A., Anderson, S. E., McDermott, E., \& Sedaca, M. (2017). Factors that promote high school graduation: A review of the literature. Educational Psychology Review, 29, 447-476. https://doi.org/10.1007/s10648-016-9363-5.

Publisher's Note Springer Nature remains neutral with regard to jurisdictional claims in published maps and institutional affiliations.

Jan Arvid Haugan is an associate professor at the Department of Education and Lifelong Learning at the Norwegian University of Science and Technology, and teaches in themes related to school counselling for children and adolescents. His research interests are coping, resilience, dropout and mental health in schools. 
Per Frostad is a professor in Special Education at the Department of Education and Lifelong learning at the Norwegian University of Science and Technology. His research interests are social inclusion and learning for students with special educational needs, teacher-student relations, and psychological adjustment and wellbeing for students in school.

Per Egil Mjaavatn is an associate professor at the Department of Education and Lifelong learning at the Norwegian University of Science and Technology. His research interests are social inclusion and learning for students with special educational needs, teacher-student relations, and psychological adjustment and wellbeing for students in school. 